\title{
Dermatological manifestations of COVID-19 and its therapies: a review
}

\author{
Heena Singdia, Rachita Mathur, Shivi Nijhawan, Neha Rani, Deepika Kothari, \\ Rohit Garg, Puneet Bhargava*, Deepak K. Mathur
}

Department of Skin, SMS medical college and hospital, Jaipur, Rajasthan, India

Received: 27 November 2020

Revised: 01 January 2021

Accepted: 05 January 2021

\section{*Correspondence:}

Dr. Puneet Bhargava,

E-mail: puneetbhargava.pb@gmail.com

Copyright: (C) the author(s), publisher and licensee Medip Academy. This is an open-access article distributed under the terms of the Creative Commons Attribution Non-Commercial License, which permits unrestricted non-commercial use, distribution, and reproduction in any medium, provided the original work is properly cited.

\begin{abstract}
In the beginning of the COVID-19 pandemic when we were still getting used to the rising cases every day and limited resources to deal them with, the focus was to get a hold of the situation as quickly as possible. Seven months into the pandemic, the cases are still on the rise but we have gathered some knowledge through the researches getting published every day, most of which are focused on the involvement of respiratory system, cardiovascular system, central nervous system, and gastrointestinal system. Dermatological manifestations have not been given their due importance. Lately, many patients have started presenting with dermatological manifestation sometimes preceding or sometimes during COVID-19 infection with or without involvement of other systems. This may be beneficial to clinicians all over the world, to determine potential dermatological signs in COVID-19 and also help in earlier suspection of the COVID-19 infection. Many cutaneous adverse drug reactions (ADR) to drugs advocated in COVID19 treatment are also being reported every day, which are discussed in this review.
\end{abstract}

Here we attempt to review dermatological manifestations of COVID-19 infections and drug reactions by the drugs advocated for its treatment and an understanding in its path mechanisms reported thus far. This will help clinicians to get an insight into what to expect and when to expect in terms of dermatological manifestation of COVID-19 and its drugs.

Keywords: COVID-19, SARS-CoV2, Cutaneous manifestation, COVID toes, Acrocyanosis, Vasculitis

\section{INTRODUCTION}

SARS-CoV2 (severe acute respiratory syndrome coronavirus-2), a novel coronavirus was first reported in December of 2019 from Wuhan, China, as an etiological agent causing a new infectious respiratory disease (coronavirus disease 2019, COVID-19). ${ }^{1}$

SARS-CoV-2 spread rapidly worldwide through humanto-human transmission following which COVID-19 was declared as a pandemic emergency by world health organization (WHO) on March, 2020.
By October $14^{\text {th }} 2020,38,363,705$ patients were confirmed as COVID-19 cases and total toll of death reaching up to $1,090,811$ patients.

The main clinical manifestations of COVID-19 being fever, cough, fatigue, dyspnoea and muscle aches. ${ }^{2,3}$ The diarrhoea, olfactory and gustatory impairments are some recent symptoms to join the list occurring in $5-15 \%$ of patients. ${ }^{4,5}$ The skin being the largest organ of the body was not very far from becoming prey to COVID19 virus.

The main dermatological manifestations were classified under 5 classes as of- 
Erythematous rash: Erythematous rash (47\%) (morbilliform, maculopapular, papulosquamous. Generally, appear within 6 days of appearance of first symptom of COVID-19 and involve legs, thighs, forearms, arms, shoulders, back, chest and abdomen. ${ }^{6}$

Urticarial eruptions: Urticarial eruptions (19\%) pruritic wheals and plaques, appear on 2-5 days of disease and involve entire body while in case of urticarial vasculitis involvement of trunk and limbs is seen.

Varicella like vesicular eruptions: Nine percent chicken pox like vesicles on an erythematous background predominantly appear on trunk and limbs with mean duration of appearance being 5 days of disease onset. ${ }^{8}$

Acral lesions (COVID toes): Nineteen percent acral ischemia leads to formation of pseudochilblains like lesions over distal extremities (hands and feet) with mean duration appearance being 8 days. ${ }^{9}$

Livedoid eruptions: Livedoid eruptions (6\%) a retiform pigmentation predominantly over lower extremities seldom breaking into ulcers which heal onto give porcelain white scarring presents on 1-3 days of disease onset. $^{10}$

Recently two more classes acrocyanosis bluish discoloration of fingers and toes which appears as early as third day of disease onset and Retiform purpura appearing on 5-15 days of disease onset predominantly involving buttocks, back and abdomen. ${ }^{11,12}$
Were added to the pre-existing list of symptoms along with many other isolated cases of different cutaneous features.

Based on the evidence published to date, the cutaneous manifestations of novel coronavirus are similar to those caused by other common viral infections, all owing to their mostly similar pathogenesis.

The rashes (morbilliform, papulosquamous) characteristic of the acute phase of the inflammatory response generated by viral infection, could appear early in infection. Whereas Acral lesions and/or chilblain-like lesions (COVID toes) could be a late manifestation of inflammatory processes or microthrombotic events in the immune phase of disease. ${ }^{13}$ Some studies tried to establish a temporal relationship between skin lesions and the severity of systemic symptoms. For e.g.- pseudochilblain was associated with less severe pulmonary disease in contrast to livedoid presentations which were associated with worse pulmonary involvement. ${ }^{14}$

\section{CLASSIFICATION OF SKIN LESIONS DUE TO SARS COV2}

After reviewing many articles and case reports on dermatological manifestations of COVID-19 worldwide, we got the understanding that some clinical features were more commonly found, while some were individual presentations. Hence, we decided to categorize all the features into established presentations and isolated presentations in their respective age groups (Table 1). ${ }^{15-25}$

Table 1: Classification of dermatological manifestations in COVID-19 patients in their respective age groups.

\begin{tabular}{|c|c|c|c|}
\hline \multicolumn{2}{|l|}{ Adult } & \multicolumn{2}{|l|}{ Paediatric } \\
\hline Established & Isolated & Established & Isolated \\
\hline $\begin{array}{l}\text { Erythematous rash- } \\
\text { Morbilliform rash, } \\
\text { Maculopapular rash, } \\
\text { papulosquamous rash }\end{array}$ & $\begin{array}{l}\text { Symmetrical drug-related } \\
\text { intertriginous and flexural } \\
\text { exanthema (SDRIFE)- } \\
\text { like erythematous rash }\end{array}$ & $\begin{array}{l}\text { Hand-foot-mouth } \\
\text { disease }\end{array}$ & $\begin{array}{l}\text { Acute haemorrhagic } \\
\text { edema of infancy }\end{array}$ \\
\hline $\begin{array}{l}\text { Urticaria and } \\
\text { Urticarial vasculitis }\end{array}$ & Idiopathic plantar hidradenitis & $\begin{array}{l}\text { Chickenpox like } \\
\text { vesicles }\end{array}$ & Ulcerated facial skin \\
\hline $\begin{array}{l}\text { Vesiculobullous rashes- } \\
\text { Varicella-like papulovesicular } \\
\text { exanthema }\end{array}$ & Neutrophilic dermatosis & $\begin{array}{l}\text { Varicella-like } \\
\text { exanthem }\end{array}$ & \\
\hline $\begin{array}{l}\text { Acral ischemia-Lupus } \\
\text { erythematosus (LE)-like } \\
\text { chilblains of feet (COVID toes) }\end{array}$ & Acute acral cyanosis & $\begin{array}{l}\text { P. Rosea like } \\
\text { lesions }\end{array}$ & \\
\hline $\begin{array}{l}\text { COVID-19-related vasculitis- } \\
\text { Livedo reticularis }\end{array}$ & COVID red half-moon nail sign & Maculopapular rash & \\
\hline $\begin{array}{l}\text { Erythema multiforme like } \\
\text { lesions }\end{array}$ & Dengue like Petechial rash & Kawasaki disease & \\
\hline Retiform purpura & Androgenetic alopecia (AGA) & & \\
\hline \multirow{3}{*}{$\begin{array}{l}\text { Acute generalized } \\
\text { exanthematous pustulosis } \\
\text { (AGEP)-like rash }\end{array}$} & $\begin{array}{l}\text { Pigment disorders-Diffuse } \\
\text { melanoderma of acute onset } \\
\text { (periorbital dyschromia) }\end{array}$ & & \\
\hline & Dry gangrene & & \\
\hline & Eosinophilic panniculitis & & \\
\hline
\end{tabular}




\section{Histopathological findings in COVID-19 skin}

In maculopapular eruptions: Epidermis shows dyskeratotic cells, ballooning multinucleated cells and sparse necrotic keratinocytes with lymphocytic satellitosis and nests of Langerhans cells. In Dermisdiffuse telangiectatic blood vessels, Perivascular spongiotic dermatitis and a dense perivascular lymphocytic infiltration eosinophilic rich around swollen blood vessels with extravasated erythrocytes are seen. Edematous dermis with many eosinophils, cuffs of lymphocytes around blood vessels in lymphocytic vasculitis and intravascular microthrombi in small dermal vessels is present. ${ }^{26}$

In cases of urticaria like rash: Superficial perivascular inflammation with eosinophils and lichenoid pattern, and sometimes Slight vacuolar-type interface dermatitis with occasional necrotic keratinocytes may be seen. ${ }^{27}$

In cases of vasculitis: An inflammatory infiltrate in wall of dermal or subcutaneous vessels (which can be neutrophilic, lymphocytic, or granulomatous), red blood cell extravasation, variable fibrinoid necrosis of vessel walls, and leucocytoclasia is seen. Further on DIF staining, deposits of immunoglobulin, complement, or fibrin in the vessel wall can be seen. ${ }^{28}$

In case of vesicobullous eruptions: Vacuolar degeneration of the basal layer with multinucleate, hyperchromatic keratinocytes and dyskeratotic cells with mixed inflammatory infiltrate are present. ${ }^{29}$

In cases of livedoid vasculopathy: Thrombogenic vasculopathy accompanied by extensive deposition of C5b- 9 and C4d within the microvasculature are seen. ${ }^{30}$

In cases of acral pernios: A diffuse dense lymphoid infiltrate of the superficial and deep dermis, and signs of endothelial activation (swelling and infiltration) with mild superficial perivascular dermatitis are present. ${ }^{31}$

\section{Pathogenetic mechanism of dermatological manifestations in COVID-19}

The pathological mechanisms of skin lesions in COVID19 patients remain poorly understood.

Cutaneous manifestations in COVID-19 may be classified into two major groups regarding their pathomechanisms- (A) Clinical features similar to viral exanthems, due to direct effect of COVID19 virus. (B) Cutaneous eruptions secondary to systemic consequences caused by COVID-19 (especially vasculitis and thrombotic vasculopathy). ${ }^{32}$

SARS-CoV-2 is a single-stranded RNA virus composed of 16 non-structural proteins (NSP 1-16) with specific roles in the replication of coronaviruses. ${ }^{33}$ Where, NSP3 has the ability to block the host's innate immune response and promote cytokine expression, while NSP5 can inhibit interferon (IFN) signalling, and NSP16 avoids MAD5 (melanoma differentiation-associated gene recognition, while depressing innate immunity. ${ }^{34}$

Different morphological lesions and pathogenesis implicated in their appearance- Vesicular lesions have been commonly described with COVID-19. Pathogenesis has been poorly understood; however, the presence of multinucleated ballooning cells suggests a direct cytopathic effect, lending weight to the hypothesis that lesions are due to COVID-19 virus related cytopathy. ${ }^{35}$

COVID-19 progression is related to an extreme rise in inflammatory cytokines including interleukin (IL)2, IL7, IL10, GCSF, IP10, MCP1, MIPI A, and TNF $\alpha$. The increase in the pro-inflammatory cytokines, in particular, IL6 is associated with severe pneumonia and it can have deleterious effects on the adaptive immune system. ${ }^{36}$ In these subsets of patients, overactive immune responses may induce immunopathological conditions, named as cytokine storm and in some individuals leads to macrophage activation syndrome (MAS)-like, often causing a fatal outcome.$^{37}$ Cytokines could reach the skin and stimulate dermal dendritic cells, macrophages, mast cells and lymphocytes, in addition to polymorphonuclear cells and promote eruptions such as erythema, urticarial lesions, vesicles and others.

Hammining et al identified the metallopeptidase named angiotensin-converting enzyme 2 (ACE2) as the functional receptor for SARS-CoV responsible for an epidemic outbreak during 2003-2004. ${ }^{38}$ Using IHC methods, it was found that the surface expression of ACE2 protein was present on lung alveolar epithelial cells (pneumocytes), macrophages, enterocytes of the small intestine, arterial and venous endothelial cells, arterial smooth muscle cells including the skin in the basal layer of the epidermis, endothelial cells of dermal blood vessels and eccrine adnexal tissue. ${ }^{39}$ The ACE2 receptor is also widely expressed on endothelial cells in multiple organs, suggesting that endotheliitis could occur in several sites as a direct consequence of viral involvement and host inflammatory response.

Varga et al revealed viral inclusion structures in endothelial cells across vascular beds of different organs in some patients with COVID-19. ${ }^{40}$ This showed direct viral infection of endothelial cell and diffuse endothelial inflammation. COVID-19-endotheliitis could explain the systemic impaired microcirculatory function in different vascular beds and their clinical sequelae in patients with COVID-19. SARS-CoV2 binds to ACE2 by spike protein (S) and this allows entry of virus inside the cell. ${ }^{41}$ In order for virus to complete entry into the cell following this initial process, the spike protein has to be primed by a protease (TMPRSS2) to complete this process. ${ }^{42}$ The expression of this protease (TMPRSS2) is androgen dependent, and this maybe the reason why males are more commonly and severely affected by COVID- $19 .{ }^{43}$ 
Complement activation (C5b-9 and C4d) by SARS-CoV2 spike glycoproteins has been seen in retiform purpura. In pseudo chilblain and purpuric lesions, an obliterative microangiopathy consisting of endothelial and intensive myointimal growth with complement activation has been observed. This mechanism, together with increased vascular permeability, could contribute to obliterative vascular lumen and haemorrhage in COVID patients. ${ }^{44}$

A proper understanding of these pathomechanisms will help in formulating newer therapies for treating dermatological manifestations of COVID-19.
There has always been a diagnostic dilemma regarding the origin of cutaneous features in the course of COVID19 infection, whether the dermatological signs are a result of COVID-19 infection or just an ADR to the drugs implicated in the treatment of patient. Keeping Proper timeline of the appearance of lesions and monitoring and correlating the severity of COVID symptoms with dermatological manifestation may help to rule out the underlying cause in some crossover cases.

Here we are discussing some common drugs advocated in treatment of COVID worldwide and summarising some common drug reactions reported by them (Table 2). ${ }^{45}$

Table 2: Drugs advocated in treatment of COVID-19 and cutaneous manifestation of ADR because of them.

\begin{tabular}{|c|c|}
\hline Drugs & Adverse effects \\
\hline $\begin{array}{l}\text { Antimalarials- } \\
\text { Hydroxychloroquine and chloroquine }\end{array}$ & $\begin{array}{l}\text { Acute generalized exanthematous pustulosis, } \\
\text { Urticaria, pruritus, rashes } \\
\text { Flares of psoriasis and exfoliating lesions, } \\
\text { Stevens-Johnson-like syndrome } \\
\text { Mucocutaneous dyspigmentation }\end{array}$ \\
\hline Azithromycin- & $\begin{array}{l}\text { Generalized red or purple skin rashes } \\
\text { Anaphylaxis } \\
\text { DRESS syndrome } \\
\text { Cutaneous leukocytoclastic vasculitis } \\
\text { Fixed drug eruptions. }\end{array}$ \\
\hline Colchicine & $\begin{array}{l}\text { Blanchable violaceous morbilliform rash } \\
\text { Lichenoid drug eruption } \\
\text { Alopecia } \\
\text { Toxic epidermal necrolysis-like reaction } \\
\text { Erythema-nodosum-like lesions. }\end{array}$ \\
\hline Remdesivir & Skin rashes \\
\hline Ivermectin & $\begin{array}{l}\text { Swelling of ankles and hands } \\
\text { Allergic skin reactions such as Urticaria and Rash }\end{array}$ \\
\hline Oseltamivir & $\begin{array}{l}\text { Stevens-Johnson syndrome/toxic epidermal necrolysis, } \\
\text { Angioedema } \\
\text { Allergic or an idiosyncratic cutaneous drug reaction }\end{array}$ \\
\hline Ribavirin & $\begin{array}{l}\text { Acneiform eruptions, } \\
\text { Alopecia } \\
\text { Localized scleroderma } \\
\text { Maculopapular lesions } \\
\text { Skin dryness, Pruritus and rash }\end{array}$ \\
\hline Interferons & $\begin{array}{l}\text { Injection site reactions, } \\
\text { Psoriasis } \\
\text { Alopecia } \\
\text { Sarcoidosis } \\
\text { Lupus } \\
\text { Cutaneous vasculitis lesions } \\
\text { Lichenoid drug reactions }\end{array}$ \\
\hline Protease inhibitors (ritonavir/lopinavir) & $\begin{array}{l}\text { Maculopapular drug eruptions } \\
\text { Exfoliative erythroderma } \\
\text { Stevens-Johnson syndrome or TEN } \\
\text { Injection site reactions }\end{array}$ \\
\hline Corticosteroids & $\begin{array}{l}\text { Acneiform eruptions } \\
\text { Folliculitis } \\
\text { Skin atrophy } \\
\text { Telangiectasia } \\
\text { Hirsutism } \\
\text { Stria }\end{array}$ \\
\hline
\end{tabular}




\begin{tabular}{|ll|}
\hline Drugs & Adverse effects \\
\hline Tocilizumab & Skin hypersensitivity reactions, \\
& Psoriasiform dermatitis \\
\hline \multirow{3}{*}{ Anakinra } & Skin rashes \\
& Injection-site reactions \\
& Cellulitis \\
\hline JAK inhibitors (Baricitinib) & Palmoplantar pustulosis-like eruption \\
& Herpes zoster and simplex activations \\
& Melanoma and nonmelanoma skin cancers \\
& Urticaria, Rash, Angioedema \\
\hline \multirow{3}{*}{ Anti-TNF biologics (Adalimumab) } & Psoriasiform-like lesions \\
& Lupus-like syndromes \\
& Cutaneous vasculitis \\
& Granulomatous reactions \\
\hline IVIG treatments & Anaphylactic reaction \\
& Facial vasculitis rash \\
& Maculopapular rashes \\
& Erythema multiforme \\
\hline Zinc supplementation & Alopecia \\
\hline Vitamin C & Generalised dilution in skin color \\
& Menkes kinky hair disease \\
& Trichoptilosis \\
\hline
\end{tabular}

\section{ANTIMALARIALS}

Hydroxychloroquine and chloroquine have antiviral activity against COVID-19 in vitro and smalluncontrolled clinical studies and has been the mainstay for treatment as well as prophylaxis for health care workers in the beginning of pandemic.

Cutaneous adverse events of antimalarials include cutaneous eruptions such as acute generalized exanthematous pustulosis, urticaria, pruritus, dry skin, rashes, flares of psoriasis and exfoliating lesions, Stevens-Johnson-like syndrome, mucocutaneous dyspigmentation, alopecia and bleaching of hair. ${ }^{45}$

\section{Azithromycin}

In the recent treatment guidelines issued by AIIMS New Delhi, azithromycin is indicated in all mildly symptomatic patients practicing home quarantine. Azithromycin has immunomodulatory and antiinflammatory properties hence Combining hydroxychloroquine with the antibiotic azithromycin has been associated with positive patient outcomes according to a low-powered French study Skin adverse events of azithromycin are generalized red or purple skin rashes, blistering, skin peeling, toxic pustuloderma, anaphylaxis, DRESS syndrome, cutaneous leukocytoclastic vasculitis, and fixed drug eruptions. ${ }^{45}$

\section{Colchicine}

Colchicine is being used for its anti-neutrophilic immunomodulatory effect; it decreases the chances of severe pulmonary involvement, organ failure, and death which are due to cytokine storm and inflammatory process. Skin side-effects of colchicine include diffuse, blanchable, violaceous, morbilliform rash, lichenoid drug eruption, alopecia, toxic epidermal necrolysis-like reaction, erythema-bullous, and erythema-nodosum-like lesions. ${ }^{45}$

\section{Remdesivir}

It is being advocated in moderately symptomatic hospitalised patients of COVID-19 and with CT score $>12$ according to their recent CT scan chest. Remdesivir shuts down viral replication by inhibiting a key viral enzyme, the RNA polymerase. The drug, which is given intravenously, and the most common adverse events is skin rashes. ${ }^{45}$

\section{Oseltamivir}

This has also been approved for the treatment of pandemic influenza A and B treatments. Oseltamivir inhibits the viral neuraminidase and, blocks the release of viral particles from host cells. Oseltamivir can cause Stevens-Johnson syndrome/toxic epidermal necrolysis, angioedema, allergic, or idiosyncratic cutaneous drug reactions. ${ }^{45}$

\section{Favipiravir}

Favipiravir is a nucleoside analogue that is well-known as a broad-spectrum antiviral drug with a lower side-effects profile. Its oral preparation recently being marketed under the name of FABIFLU is being widely used in mildly 
symptomatic cases of COVID-19. No significant data was collected regarding the cutaneous side effect of favipravir. ${ }^{45}$

\section{Umifenovir}

inhibits membrane fusion of the viral envelope and spike $\mathrm{S}$ protein/ACE2 interaction. Basically, inhibiting the fusion and entry of virus inside the cells. There are no reports on the skin reaction of umifenovir. ${ }^{45}$

\section{Ribavirin}

It is a broad antiviral against respiratory viruses such as influenza A and B viruses and parainfluenza 1 virus. Side effects of ribavirin include acneiform eruptions, alopecia, localized scleroderma, maculopapular, and eczematous lesions, skin dryness, pruritus, and rash. ${ }^{45}$

\section{Interferon alpha-2a}

interact with the toll-like receptors and can inhibit the viral replication. Cutaneous side-effects of interferons are injection site reactions, psoriasis, eczematous drug reactions, alopecia, sarcoidosis, lupus, cutaneous vasculitic lesions, psoriasis, and lichenoid drug reactions. ${ }^{45}$

\section{Protease inhibitors (ritonavir/lopinavir)}

These agents inhibit 3-chymotrypsin-like protease. Cutaneous adverse events of antiretroviral drugs include maculopapular drug eruptions, exfoliative erythroderma, Stevens-Johnson syndrome or toxic epidermal necrolysis. $^{45}$

\section{Ivermectin}

It has antimicrobial, anti-cancer properties and antiviral properties against wide range of viruses including SARSCOV2. It acts by inhibiting the host importin alpha/beta-1 nuclear transport proteins, which are part of a key intracellular transport process that viruses hijack to enhance infection by suppressing the host antiviral response. $^{45}$

Some of the cutaneous side-effects include, swelling of ankles and hands and allergic skin reactions such as urticaria, rash, redness.

\section{Steroids}

Short term Corticosteroids have anti-inflammatory functions and they can suppress the inflammation during COVID-19 associated acute respiratory distress syndrome. Skin side-effects of steroids include folliculitis, acneiform eruptions, skin atrophy, telangiectasia, erythema, edema, acne, hirsutism, and stria. $^{45}$

\section{Barcitinib}

Janus kinase (JAK) inhibitors block viral entry into pneumocytes and can inhibit inflammatory mechanisms in COVID-19 infection. Palmoplantar pustulosis-like eruption, allergic skin rashes, herpes simplex, and herpes zoster infections, melanoma and nonmelanoma skin cancers, urticaria, rash, angioedema are some of the cutaneous side effects. ${ }^{45}$

\section{Tocilizumab}

Tocilizumab, a humanized monoclonal antibody against IL-6 receptors, which is the chief cytokine responsible for the uncontrolled cytokine and chemokine response known as a "cytokine storm," and this condition leads to the over-activation of effector $\mathrm{T}$ cells and production of pro-inflammatory cytokines. Skin infection, pruritus, skin hypersensitivity reactions, psoriasiform dermatitis are the cutaneous side-effects of tocilizumab. ${ }^{45}$

\section{Anti-IL 1 (Anakinra)}

IL-1 blockade with anakinra helps in checking hyper inflammation during COVID-19 infection. Cutaneous side-effects of anakinra include rash, injection-site reactions, and skin infections such as wound infection, cellulitis. ${ }^{45}$

\section{Anti TNF- $\alpha$ biologicals}

Severity of COVID-19 corresponds to the Higher TNF- $\alpha$ levels; hence adalimumab has been tried with success in some patients. Cutaneous side-effects of anti-TNFs include infusion and injection site reactions, psoriasis and psoriasiform-like lesions, lupus-like syndromes, cutaneous vasculitis, cutaneous infections, eczematous reactions, lichenoid eruptions, granulomatous reactions, cutaneous lymphoma, epithelial skin cancers or melanoma. $^{45}$

\section{INTRAVENOUS IMMUNOGLOBULIN (IVIG)}

High-dose intravenous immunoglobulin (IVIG) collected from recovered Coronavirus-19 patients may protect against COVID-19 and strengthen the immune system of new severe and treatment-resistant patients. Skin adverse events of IVIG treatments include anaphylactic reaction, facial vasculitic rash, urticaria, maculopapular rashes, petechiae, eczema, erythema multiforme, and alopecia. ${ }^{45}$

\section{Zinc}

Elemental zinc $(50 \mathrm{mg}$ ) supplementation is also advised in mildly symptomatic cases of COVID-19. Increased intracellular zinc concentrations efficiently impair replication in a number of RNA viruses. Zinc along with chloroquine has been shown to enhance cytotoxicity and induce apoptosis. ${ }^{46}$ 
There are no cutaneous adverse events reported thus far but long-term zinc supplementation can cause copper deficiency, hence it is advised to keep a close eye on signs of copper deficiency like generalised skin color dilution and Menke's kinky hair disease in future. ${ }^{47}$

\section{Vitamin C}

It is an antioxidant with anti-inflammatory properties, influences cellular immunity and vascular integrity. ${ }^{48}$ There is potential role of high doses of vitamin $\mathrm{C}$ in ameliorating inflammation and vascular injury in serious cases of COVID-19 causing sepsis and acute respiratory distress syndrome (ARDS). Hence it is now recommended in mild symptomatic cases practicing quarantine at home. No side effects are reported so far, because of water soluble nature of vitamin C. ${ }^{49}$

\section{CONCLUSION}

In the era of COVID-19 pandemic, where we see more and more publications stating various unforeseen presentations of COVID-19 infection, there is limited research when it comes to its cutaneous manifestations. COVID-19 being a viral illness, its cutaneous manifestations are similar to any viral illness and more.

Lately, many patients present with dermatological manifestation seldom preceding and in majority during COVID-19 infection. The order of appearance of these manifestations in combination with other symptoms of COVID-19 have major diagnostic and prognostic value.

Many cutaneous adverse drug reactions to drugs advocated in COVID-19 treatment are also being reported and with the fast-developing vaccine against COVID-19, getting to know the side effects of every drug is paramount, so that every clinician will get an insight into what to expect and when to expect in terms of dermatological manifestation of COVID-19 and its drugs. Through this article, we tried to present a brief review of some of the current cutaneous abnormalities observed in patients of COVID-19 perse and due to the drugs advocated for its treatment.

Funding: No funding sources

Conflict of interest: None declared

Ethical approval: Not required

\section{REFERENCES}

1. Huang C, Wang Y, Li X, Ren L, Zhao J, Hu Y et al. Clinical features of patients infected with 2019 novel coronavirus in Wuhan, China. Lancet. 2020;395:497506.

2. Lovato A, Filippis C. Clinical presentation of COVID-19: a systematic review focusing on upper airway symptoms. Ear Nose Throat J. 2020;99(9):569-76.
3. Fang Z, Yi F, Wu K, Laic K, Suna X, Zhong N et al. Clinical characteristics of coronavirus pneumonia 2019 (COVID-19): an updated systematic review. medRxiv. 2020.

4. Liang W, Feng Z, Rao S, Xiao C, Xue X, Lin Z et al. Diarrhoea may be underestimated: a missing link in 2019 novel coronavirus. Gut. 2020;69:1141-3.

5. Xydakis M, Dehgani-Mobaraki P, Holbrook E et al. Smell and taste dysfunction in patients with COVID19. Lancet Infect Dis. 2020.

6. Mahé A, Birckel E, Krieger S, Merklen C, Bottlaender L. A distinctive skin rash associated with coronavirus disease 2019? J Eur Acad Dermatol Venereol. 2020;34(6):e246-7.

7. Henry D, Ackerman M, Sancelme E, Finon A, Esteve E. Urticarial eruption in COVID-19 infection. J Eur Acad Dermatol Venereol. 2020;34(6):e244-5.

8. Marzano AV, Genovese G, Fabbrocini G, Pigatto P, Monfrecola G, Piraccini BM. Varicella-like exanthem as a specific COVID-19-associated skin manifestation: multicenter case series of 22 patients. J Am Acad Dermatol. 2020;83(1):280-5.

9. Al Ramthan A, Al Daraji W. A case of COVID-19 presenting in clinical picture resembling chilblains disease. First report from the Middle East. Clin Exp Dermatol. 2020;45(6):746-8.

10. Manalo IF, Smith MK, Cheeley J, Jacobs R. A dermatologic manifestation of COVID-19: transient livedo reticularis. J Am Acad Dermatol. 2020;83(2):700.

11. Zhang Y, Cao W, Xiao M, Li YJ, Yang Y, Zhao J et al. Clinical and coagulation characteristics of 7 patients with critical COVID-2019 pneumonia and acro-ischemia. Zhonghua Xue Ye Xue Za Zhi. 2020;41:E006.

12. Zhang Y, Xiao M, Zhang S. Coagulopathy and antiphospholipid antibodies in patients with COVID19. N Engl J Med. 2020;382(17):e38.

13. Türsen Ü, Türsen B, Lotti T. Coronavirus-days in dermatology. Dermatol Ther. 2020;33(4):e13438.

14. Casas GC, Català A, Carretero Hernández G, Rodríguez-Jiménez P, Fernández-Nieto D, Rodríguez-Villa Lario A, et al. Classification of the cutaneous manifestations of COVID-19: a rapid prospective nationwide consensus study in Spain with 375 cases. Br J Dermatol. 2020;183(1):71-7.

15. Recalcati S. Cutaneous manifestations in COVID-19: a first perspective. J Eur Acad Dermatol Venereol. 2020;34(5):e212-3.

16. Fernandez-Nieto D, Ortega-Quijano D, SeguradoMiravalles G. Comment on: Cutaneous manifestations in COVID-19: a first perspective. Safety concerns of clinical images and skin biopsies. J Eur Acad Dermatol Venereol. 2020;34(6):e252-4.

17. Jimenez-Cauhe J, Ortega-Quijano D, Prieto-Barrios $\mathrm{M}$, et al. Reply to "COVID-19 can present with a rash and be mistaken for Dengue, Petechial rash in a 
patient with COVID-19 infection. J Am Acad Dermatol. 2020;83(2):e141-2.

18. Estébanez A, Pérez-Santiago L, Silva E, et al. Cutaneous manifestations in COVID-19: a new contribution. J Eur Acad Dermatol Venereol 2020.

19. Otto MA. Skin manifestations are emerging in the coronavirus pandemic. Dermatology News April 3, 2020. Available at: https://www.mdedge.com/ dermatology/article/220183/coronavirusupdates/skin-manifestations-are-emergingcoronavirus-pandemic. Accessed on 6 May 2020.

20. Joob B, Wiwanitkit V. COVID-19 can present with a rash and be mistaken for Dengue. J Am Acad Dermatol. 2020;82(5):e177.

21. Gianotti R, Veraldi S, Recalcati S, Cusini M, Ghislanzoni M, Boggio F, et al. Cutaneous ClinicoPathological Findings in three COVID-19-Positive Patients Observed in the Metropolitan Area of Milan, Italy. Acta Derm Venereol. 20203;100(8):adv00124.

22. De Perosanz-Lobo D, Fernandez-Nieto D, BurgosBlasco P, Selda-Enriquez G, Carretero I, Moreno C, et al. Urticarial vasculitis in COVID-19 infection: A vasculopathy-related symptom? J. Eur Acad Dermatol Venereol. 2020;34(10):e566-8.

23. Mahé A, Birckel E, Merklen C, Lefèbvre $P$, Hannedouche C, Jost M, Droy-Dupré L. Histology of skin lesions establishes that the vesicular rash associated with COVID-19 is not 'varicella-like'. J Eur Acad Dermatol Venereol. 2020;34(10):e559e561.

24. Cordoro KM, Reynolds SD, Wattier R, McCalmont TH. Clustered Cases of Acral Perniosis: Clinical Features, Histopathology and Relationship to COVID-19. Pediatr. Dermatol. 2020;37(3):419-23.

25. Drago F, Ciccarese G, Gasparini G. Contemporary infectious exanthems: an update. Future Microbiol. 2017;12:171-93.

26. Chen Y, Liu Q, Guo D. Emerging coronaviruses: genome structure, replication, and pathogenesis. J Med Virol. 2020;92(4):418-23.

27. Prompetchara E, Ketloy C, Palaga T. Immune responses in COVID-19 and potential vaccines: lessons learned from SARS and MERS epidemic. Asian Pac J Allergy Immunol. 2020;38(1):1-9.

28. Sharlala H, Adebajo A. Virus-induced vasculitis. Curr Rheumatol Rep. 2008; 10(6): 449- 452.

29. Gansner JM, Berliner N. The rheumatology/hematology interface: CAPS and MAS diagnosis and management. Hematology Am Soc Hematol Educ Program. 2018;2018(1):313-7.

30. Hamming I, Timens W, Bulthuis ML, Lely AT, Navis G, van Goor H. Tissue distribution of ACE2 protein, the functional receptor for SARS coronavirus. A first step in understanding SARS pathogenesis. J Pathol. 2004;203(2):631-7.

31. Soler MJ, Batlle M, Riera M, Campos B, Ortiz-Perez JT, Anguiano L, et al. ACE2 and ACE in acute and chronic rejection after human heart transplantation. Int J Cardiol. 2019;275:59-64.

32. Varga Z, Flammer AJ, Steiger P, Haberecker M, Andermatt R, Zinkernagel AS, et al. Endothelial cell infection and endotheliitis in COVID-19. Lancet. 2020;395(10234):1417-8.

33. Heurich A, Hofmann-Winkler H, Gierer S, Liepold T, Jahn O, Pöhlmann S. TMPRSS2 and ADAM17 cleave ACE2 differentially and only proteolysis by TMPRSS2 augments entry driven by the severe acute respiratory syndrome coronavirus spike protein. J Virol. 2014;88(2):1293-307.

34. Mousavizadeh L, Ghasemi S. Genotype and phenotype of COVID-19: their roles in pathogenesis. J Microbiol Immunol Infect. 2020.

35. Wambier CG, Goren A. SARS-COV-2 infection is likely to be androgen mediated. J Am Acad Dermatol. 2020;83(1):308-9.

36. Magro C, Mulvey JJ, Berlin D, Nuovo G, Salvatore S, Harp J, et al. Complement associated microvascular injury and thrombosis in the pathogenesis of severe COVID-19 infection: a report of five cases. Transl Res. 2020;220:1-13.

37. COVID-19 Treatment Guidelines Panel. Coronavirus Disease 2019 (COVID-19) Treatment Guidelines. National Institutes of Health. Available at https://www.covid19treatmentguidelines.nih.gov/. Accessed 10 November 2020.

38. Velthuis AJ, van den Worm SH, Sims AC, Baric RS, Snijder EJ, van Hemert MJ. $\mathrm{Zn}(2+)$ inhibits coronavirus and arterivirus RNA polymerase activity in vitro and zinc ionophores block the replication of these viruses in cell culture. PLoS Pathog. 2010;6(11):e1001176.

39. Altarelli M, Ben-Hamouda N, Schneider A, Berger MM. Copper Deficiency: Causes, Manifestations, and Treatment. Nutr Clin Pract. 2019;34(4):504-13.

40. Wei XB, Wang ZH, Liao XL, et al. Efficacy of vitamin $C$ in patients with sepsis: an updated metaanalysis. Eur J Pharmacol. 2020;868:172889.

41. Fisher BJ, Seropian IM, Kraskauskas D, et al. Ascorbic acid attenuates lipopolysaccharide-induced acute lung injury. Crit Care Med. 2011;39(6):145460 .

Cite this article as: Singdia H, Mathur R, Nijhawan S, Rani N, Kothari D, Garg R, et al. Dermatological manifestations of COVID-19 and its therapies: a review. Int J Res Dermatol 2021;7:346-53. 